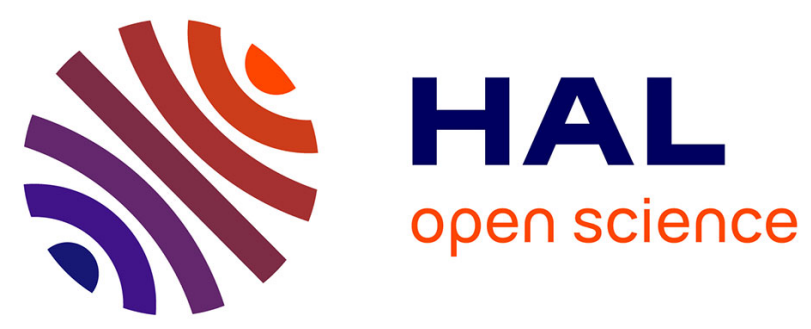

\title{
Changes in calculated residual energy in variable nutritional environments: An indirect approach to apprehend suckling beef cows' robustness
}

Anne de La Torre Capitan, Emilie Recoules, Fabienne Blanc, Isabelle Ortigues Marty, Pascal P. d'Hour, Jacques Agabriel

\section{To cite this version:}

Anne de La Torre Capitan, Emilie Recoules, Fabienne Blanc, Isabelle Ortigues Marty, Pascal P. d'Hour, et al.. Changes in calculated residual energy in variable nutritional environments: An indirect approach to apprehend suckling beef cows' robustness. Livestock Production Science, 2015, 176, pp.75-84. 10.1016/j.livsci.2015.03.008 . hal-02634821

\section{HAL Id: hal-02634821 \\ https://hal.inrae.fr/hal-02634821}

Submitted on 27 May 2020

HAL is a multi-disciplinary open access archive for the deposit and dissemination of scientific research documents, whether they are published or not. The documents may come from teaching and research institutions in France or abroad, or from public or private research centers.
L'archive ouverte pluridisciplinaire HAL, est destinée au dépôt et à la diffusion de documents scientifiques de niveau recherche, publiés ou non, émanant des établissements d'enseignement et de recherche français ou étrangers, des laboratoires publics ou privés. 


\title{
Changes in calculated residual energy in variable nutritional environments: An indirect approach to apprehend suckling beef cows' robustness
}

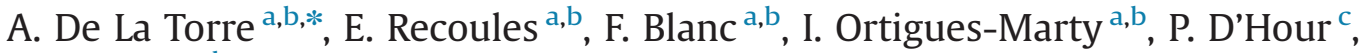 \\ J. Agabriel ${ }^{\mathrm{a}, \mathrm{b}}$ \\ a INRA, UMR1213 Herbivores, Saint-Genès-Champanelle 63122, France

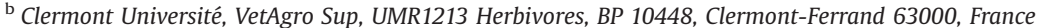 \\ ' INRA, UE1296, Unité Expérimentale des Monts d'Auvergne, Laqueuille 63820, France
}

\section{A R T I C L E I N F O}

Article history:

Received 27 August 2013

Received in revised form

5 January 2015

Accepted 15 March 2015

\section{Keywords:}

Beef cow

Robustness

Energy allocation

Nutritional trajectory

Residual energy

\begin{abstract}
A B S T R A C T
The major perturbation that beef cows have to face in extensive livestock systems is changes in feed resource availability. The ability of beef cows to face variable nutritional environments (robustness) involves adaptive processes that drive adjustments in the energy allocation toward life functions. This study proposes an indirect approach to quantify the modulation of energy allocation over a changing nutritional environment. The concept of residual energy $\left(E_{\text {resid }}\right)$, defined as the net energy intake minus the energy secreted in milk and deposited in tissues, was used to investigate the variation in energy allocation priority for maintaining productive traits. In this study robustness was assessed by the difference in $E_{\text {resid }}$ between cows experiencing either variable or non limiting nutritional trajectories and differing in body reserves at calving. Forty multiparous Charolais suckling cows, differing in their body condition at calving (moderate $(\mathrm{M}, \quad n=19)$ : $\mathrm{BCS}_{\mathrm{c}}=2.0 \pm 0.04$ (scale $\left.0-5\right)$ ) vs fat $(\mathrm{F}, \quad n=18$ ): $\mathrm{BCS}_{\mathrm{C}}=2.8 \pm 0.08$ ) were used. They were submitted to two energy levels during the first 120 days post-partum (P1): Control (MC $(n=9)$ and FC $(n=9)$ ) vs Low (ML $(n=10)$ and FL $(n=9)$ ). The average energy intake, expressed in net energy for lactation $\left(\mathrm{NE}_{\mathrm{L}}\right)$, was 90.7 and $54.7 \mathrm{MJ} / \mathrm{d} /$ cow for C and L cows, respectively. Subsequently (P2, 120-196 days post-partum) all the cows were turned out to a permanent pasture. BW, body condition and milk production were regularly measured in P1 and P2. Body lipid reserves were assessed at calving, end of P1 and end of P2 by measuring adipose cell diameter. The overall milk production was similar between groups of cows over the 2 phases of the changing nutritional trajectories highlighting the robustness of beef cows to achieve this function. During P1, L cows lost BW and body lipid reserves. During P2, BW and BCS gains were similar in FL and ML cows. At the end of P2, FL and ML cows weighed 20 and $10 \mathrm{~kg}$ less than FC and MC cows, respectively. Considering both experimental periods $(\mathrm{P} 1+\mathrm{P} 2), E_{\text {resid }}$ was $23 \%$ lower in $\mathrm{L}$ than in $\mathrm{C}$ cows $(P<0.05)$. This difference was observed regardless of $\mathrm{BCS}_{\mathrm{c}}$, showing that thin beef cows withstood the change in nutritional trajectory after calving similarly to the fatter ones. $E_{\text {resid }}$ changes reflect the ability of beef cows to preserve energy allocation toward life functions in changing nutritional environments and may be viewed as indirect criteria of robustness.
\end{abstract}

(c) 2015 Elsevier B.V. All rights reserved.

\footnotetext{
*Corresponding author at: INRA, UMR1213, 63122 Saint-GenèsChampanelle, France.

E-mail address: anne.delatorre@clermont.inra.fr (A. De La Torre).
} 


\section{Introduction}

Concept of robustness is a major concern in extensive livestock production systems where animals have to cope with environmental perturbations. In its broadest definition, the robustness is a property that accounts for the ability of system to maintain its functions despite external/or internal perturbations (Kitano, 2004). At the animal level, robustness is viewed as its ability to maintain itself (i.e. survive and produce) in a broad variety of environments or to be able to face short and long-term perturbations (Knap, 2005; Strandberg, 2009). One of the major perturbations beef cows have to cope with in extensive livestock systems is changes in feed resources' availability and quality over the productive cycle. Various studies have shown that nutrition level may affect productivity traits in beef cows such as growth, milk production, reproductive performance and longevity (Blanc et al., 2006; Jenkins and Ferrell, 1994; Osoro and Wright, 1992). However, studies mainly conducted with dairy cows revealed that life functions (growth, reproduction (including pregnancy and lactation), health...) are not affected to the same extent when the female experiences undernutrition periods. In a constrained environment, trade-offs between life-functions may occur (Blanc et al., 2006; Friggens and Newbold, 2007) as adaptation to changes in nutrients availability involves modifications in nutrient partitioning. Such modifications in resource allocation will allow for varying priorities to the robustness of some of these life functions (Douhart, 2013; Friggens and Newbold, 2007; Friggens et al., 2013). Numerous studies have considered the question of energy allocation in high-producing dairy animals. Maintenance of milk yield is a good indicator of the priority given to the milk production function. Under constraining environments milk production may decrease but nutrient allocation for lactation remains a priority and may have consequences on fertility (Blanc et al., 2006; Friggens and Newbold, 2007; Martin and Sauvant, 2010). Less attention has been paid to the robustness of suckling beef cows that would take into account trade-offs between life functions and thus between production traits (Freetly et al., 2000; Johnson et al., 2003). Indeed, contrary to dairy cows, milk yield of beef cows is moderate $(8-10 \mathrm{~kg} / \mathrm{cow} /$ day in Charolais cows) and does not change much with underfeeding reflecting the priority given to maternal investment in calf viability (Houghton et al., 1990; Petit and Agabriel, 1993).

From a systemic point of view, the cow is considered as a dynamic system that takes up energy from the environment to maintain its functions over the productive cycle. It is well documented that energy partition changes with stage of lactation (Kirkland and Gordon, 2001) and that the various metabolic pathways, e.g. lipogenesis and lipolysis, are up or down-regulated at different stages of the productive cycle (Chilliard et al., 1998; Friggens and Newbold, 2007). The net result of such changes is that all life functions are not impacted in equal proportion when nutrient supply changes. Considering such a systemic approach, net energy fluxes can be summarized using the following equation (1) $\mathrm{EI}=$ $E_{l}+E_{y}+E_{r}+E_{\text {resid, }}$, where EI represents the net energy intake, $E_{l}$ the net energy allocated to milk yield, $E_{y}$ the net energy retained by the foetus and the gravid uterus, and $E_{r}$ the net energy mobilized $\left(E_{r}<0\right)$ or retained $\left(E_{r}>0\right)$ by tissues. When net energy intake is calculated from Feed Table values, the last term of this equation, $E_{\text {resid }}$ refers to the difference between net energy intake and the theoretical energy allocated to milk production, tissue growth and reserves, so that $E_{\text {resid }}$ accounts for energy not directly allocated to productive functions. More precisely $E_{\text {resid }}$ and its variations, expressed in net energy for lactation, correspond to the energy for maintenance which covers fasting heat production, heat of voluntary activity and of thermal regulation and part of heat of fermentations, digestion, absorption and metabolism (Williams and Jenkinks, 2003), errors in measurements and estimations of intake $\left(\mathrm{NE}_{\mathrm{L}}\right.$ of milk) as well as adjustments of requirements and of partial efficiencies of utilization of diet metabolizable energy ( $\mathrm{kl}, \mathrm{kf}, \mathrm{kp})$. Individual components of $E_{\text {resid }}$ are not easily measurable in practice. Consequently, we considered that $E_{\text {resid }}$ reflects the adjustments in energy allocation which occur when the cow undergoes a changing nutritional trajectory and is proposed as a criteria to indirectly estimate robustness.

The objectives of this study were to investigate in beef cows (i) the difference in $E_{\text {resid }}$ between cows experiencing a variable nutritional trajectory (energy restriction followed by refeeding) and cows experiencing a non limiting nutritional trajectory as a criteria of adjustment in energy allocation to functions other than milk production and tissue gain, and (ii) the influence of body condition at calving on $E_{\text {resid }}$ changes.

\section{Materials and methods}

The experiment was carried out at the INRA experimental farm in Laqueuille (Auvergne, France) from January to July 2010. Animals were raised in conditions compatible with national legislation on animal care (Certificate of Authorization to Experiment on Living Animal no. 7740, Ministry of Agriculture and Fish Products, Paris, France) and was approved by the regional ethics committee (Approval no. A63.189.04).

\subsection{Experimental design}

Forty multiparous Charolais cows $(5 \pm 1.6$ years and $802 \pm 66 \mathrm{~kg}$ at calving) were involved. The experimental design was a $2 \times 2$ factorial combining two body condition scores at calving $\left(\mathrm{BCS}_{\mathrm{C}}\right.$, Fat $(\mathrm{F})$ and Moderate $(\mathrm{M})$ and two nutritional net energy levels (Control (C) and Low (L)). After calving and during the first 120 days post-partum (constraining period, P1), half of the cows experienced a nutritional restriction during the winter indoor period while the others were fed above requirements. Calving was grouped in early February. At turnout, all cows were reared at pasture in nonlimiting conditions for a 76-day period (recovery period, P2, from May to end of July). Cow-calf pairs grazed the same permanent pasture, where continuous suckling was allowed. For reproduction a bull was introduced in the herd at turnout and removed after 2 months.

\subsection{Constitution of initial body condition score}

The two groups of cows of $\mathrm{F}$ or $\mathrm{M}$ body condition were created during a 4-month pre-experimental period ( $\mathrm{P0}$, from October to calving). Groups were balanced for initial BW (F: $836 \pm 63$ and M: $845 \pm 44 \mathrm{~kg}$ ) and expected calving date. 
Table 1

Composition of feedstuffs during the pre-experimental ( $\mathrm{PO}$ ), constraining (P1) and recovery (P2) periods.

\begin{tabular}{|c|c|c|c|}
\hline & $\begin{array}{l}\text { Hay } \\
(\mathrm{P} 0+\mathrm{P} 1)\end{array}$ & $\begin{array}{l}\text { Concentrate } \\
(\mathrm{P} 0+\mathrm{P} 1)\end{array}$ & $\begin{array}{l}\text { Grass } \\
(\mathrm{P} 2)\end{array}$ \\
\hline Dry matter (\%) & 87 & 87 & 17 \\
\hline Organic matter (g/kg DM) & 897 & 838 & 932 \\
\hline $\begin{array}{l}\text { Organic dry matter } \\
\text { digestibility (\%) }\end{array}$ & $59^{\mathrm{a}}$ & $70^{\mathrm{b}}$ & $74^{c}$ \\
\hline Crude protein (g/kg DM) & 98 & 210 & 170 \\
\hline Fill value $^{\mathrm{d}}(\mathrm{kg} \mathrm{DM})$ & 1.20 & - & 1.13 \\
\hline $\begin{array}{l}\text { Net energy for lactation } \\
(\mathrm{MJ} / \mathrm{kg} \mathrm{DM})\end{array}$ & 4.6 & 7.5 & 6.8 \\
\hline
\end{tabular}

a Measured in castrated adult rams fed ad libitum according to standard INRA (2007) procedures.

b Calculated from chemical composition.

c Calculated from pepsin-cellulase in vitro digestibility.

${ }^{d}$ Fill value: reference unit of the ingestibility of feedstuffs as defined by Jarrige (1989) and INRA (2007).

Differences in body condition were obtained by supplying two levels of a common hay and commercial concentrate diet. Hay was good quality collected from permanent mountain pasture, first cut, at the beginning of the heading stage (Table 1). Amounts of hay and concentrate offered averaged per day and per cow: 10 and $4 \mathrm{~kg}$ DM for the F groups and $10 \mathrm{~kg}$ and $1 \mathrm{~kg}$ DM for the M groups, respectively. BCS was assessed every fortnight by two experienced assessors on a 0-5 scale (Agabriel et al., 1986). At the end of P0 (at calving), $\mathrm{BW}$ and $\mathrm{BCS}_{\mathrm{c}}$ of $\mathrm{F}$ and $\mathrm{M}$ cows differed by about $100 \mathrm{~kg}$ of body weight and 0.8 point of body condition score (Tables 3 and 4).

\subsection{Diets and rations during the constraining and recovery periods}

Two weeks after parturition, $\mathrm{F}$ and $\mathrm{M}$ cows were randomly allocated to one of the two energy levels: C (120\% of theoretical recommended requirements, INRA, 2007) or L (70\% of theoretical recommended requirements). These two energy levels were maintained throughout the constraining period. Diets were composed of permanent pasture hay and a commercial concentrate (INRA Bufflo Vital, Groupe Altitude, 15000 Aurillac, France) in the following proportions: 70/30 for the $\mathrm{C}$ diet and 90/10 for the $\mathrm{L}$ diet. Chemical composition of hay and commercial concentrate are given in Table 1. Net energy allowances averaged 580 and $340 \mathrm{~kJ} / \mathrm{d} / \mathrm{kg} \mathrm{BW}^{0.75}$ for the $\mathrm{F}$ and $\mathrm{M}$ groups, respectively. Rations were balanced in nitrogen supply according to INRA recommended requirements (INRA, 2007).

During the recovery period, cow-calf pairs were all reared in a rotational pasture grazing system providing good quality and non-limiting grass. Pasture was representative of permanent pasture usually found in upland areas in the Auvergne region, with little or no fertilization (0 to $40 \mathrm{~kg} \mathrm{~N} / \mathrm{ha}$ ). Grass height measurements were made before and after pasture change using an electronic plate meter. Decisions to move from one plot to the next one depended on sward height (min value: $5 \mathrm{~cm}$ ).

\subsection{Measurements, chemical analyses and calculations}

\subsubsection{Feeds}

During the constraining period, representative samples of offered hay and concentrate were taken twice weekly and pooled for chemical analyses. During the recovery period, representative grazed herbage was manually collected every week, dried in an oven $\left(60^{\circ} \mathrm{C}, 72 \mathrm{~h}\right)$. Samples were milled through a $0.85 \mathrm{~mm}$ mesh and analysed for DM, OM, nitrogen, cellulose as described in Ortigues et al. (1993), and in vitro digestibility using the pepsin-cellulase method (Aufrère et al., 2007). Separate feed samples were taken for DM determination $\left(103{ }^{\circ} \mathrm{C}, 24 \mathrm{~h}\right)$. These analyses were used to estimate the nutritive value of offered diets and grazed pasture, and the fill value of grass) (INRA, 2007). The energy value of feeds and diets was expressed in $\mathrm{NE}_{\mathrm{L}}$ according to INRA (2007).

\subsubsection{Intake}

During the constraining period, the amounts of feed offered and refused were weighed every day. During the recovery period, energy intake was individually estimated using the INRA Fill Unit system (Jarrige, 1989) as described by Faverdin et al. (2011). The Fill Unit system consists in separately predicting the intake capacity of each cow and the fill value of diets according to the references provided in the INRA (2007) tables. The Intake Capacity expressed in Fill Unit system was individually calculated as being equal to $3.2+$ $\left(0.015 \times \mathrm{BW}_{\text {calving }}\right)+(0.25 \times$ milk production $(\mathrm{kg})-[\mathrm{BCS} \times$ $\mathrm{BW}_{\text {calving }} \times(\mathrm{BCS}-2.5)$ ], where $\mathrm{BW}_{\text {calving }}$ corresponds to the body weight $(\mathrm{kg})$ after calving, milk production measured over P2, and BCS measured by handling as described previously (0-5 scale). Herbage intake ( $\mathrm{kg} \mathrm{DM} / \mathrm{cow} / \mathrm{d})$ was individually estimated by calculating the intake capacity/ grass fill value ratio.

\subsubsection{Diet digestibility}

During the recovery period digestibility of rations was measured in all cows using the ytterbium oxide $\left(\mathrm{Yb}_{2} \mathrm{O}_{3}\right)$ method (Delagarde et al., 2010). Each cow was orally dosed twice a day (at $0800 \mathrm{~h}$ and $1600 \mathrm{~h}$ ) for 10 consecutive days with a capsule containing $1 \mathrm{~g}$ of $\mathrm{Yb}_{2} \mathrm{O}_{3}$ powder using a veterinary dosing gun. During the last 5 days of this dosing period, grab samples of faeces were collected twice a day. All morning and all evening faecal samples were pooled separately for each cow. They were analysed for DM and $\mathrm{Yb}_{2} \mathrm{O}_{3}$ content by the method of Ellis et al. (1982). Faecal dry matter output was calculated for each faecal sample by dividing the daily amount of $\mathrm{Yb}_{2} \mathrm{O}_{3}$ by its corresponding faecal concentration.

\subsubsection{Milk production}

Milk production was measured every two weeks by the weigh-suckle-weigh method (Le Neindre and Dubroeucq, 1973) over both the constraining and recovery periods. During the constraining period, calves were housed in a separate pen near their dams and were allowed to suckle twice a day (at $0800 \mathrm{~h}$ and at $1600 \mathrm{~h}$ ). During the recovery period, calves were separated from their dams the evening prior to the measurement days. On each measurement day, calves were allowed to suckle twice a day (at $0800 \mathrm{~h}$ and at $1600 \mathrm{~h}$ ). Calves were weighed before and after each suckling. 
Table 2

Dry matter intakes, dry matter digestibility and net energy for lactation $\left(\mathrm{NE}_{\mathrm{L}}\right)$ intake per cow and per day: influence of body condition score at calving $\left(\mathrm{BCS}_{\mathrm{c}}\right)$ and energy level supplied during the constraining period (P1).

\begin{tabular}{|c|c|c|c|c|c|}
\hline & \multirow{2}{*}{$\begin{array}{l}\mathrm{BCS}_{\mathrm{C}}^{\mathrm{a}} \\
\text { Energy level }^{\mathrm{b}}\end{array}$} & \multicolumn{2}{|l|}{ Moderate } & \multicolumn{2}{|l|}{ Fat } \\
\hline & & Control & Low & Control & Low \\
\hline \multirow[t]{4}{*}{ P1 } & Hay $(\mathrm{kg} D \mathrm{DM} / \mathrm{d})$ & $10.7 \pm 0.1$ & $8.9 \pm 0.4$ & $11.3 \pm 0.5$ & $9.7 \pm 0.4$ \\
\hline & Concentrate $(\mathrm{kg} \mathrm{DM} / \mathrm{d})$ & $4.8 \pm 0.1$ & $1.0 \pm 0.2$ & $5.1 \pm 0.3$ & $1.3 \pm 0.1$ \\
\hline & Digestibility of DM $(\mathrm{kg} / \mathrm{kg})$ & $0.61 \pm 0.03$ & $0.57 \pm 0.02$ & $0.60 \pm 0.03$ & $0.57 \pm 0.04$ \\
\hline & $\mathrm{NE}_{\mathrm{L}}(\mathrm{MJ} / \operatorname{cow} /$ day $)$ & $87.7 \pm 5.5$ & $48.9 \pm 2.6$ & $90.7 \pm 4.8$ & $54.7 \pm 1.7$ \\
\hline P2 & $\mathrm{NE}_{\mathrm{L}}(\mathrm{MJ} /$ cow/day) & $78.4 \pm 3.4$ & $80.8 \pm 4.0$ & $78.8 \pm 4.3$ & $77.5 \pm 3.9$ \\
\hline
\end{tabular}

$\mathrm{P} 2=$ recovery period.

${ }^{\mathrm{a}} \mathrm{BCS}_{\mathrm{c}}=$ Body condition score at calving; Moderate: $\mathrm{BCS}_{\mathrm{c}}=2.0 \pm 0.04$ and Fat: $\mathrm{BCS}_{\mathrm{c}}=2.8 \pm 0.08$.

${ }^{\mathrm{b}}$ Energy levels: energy level supplied during constraining period (P1, from 0 to 120 days post-partum); Control=120\% of theoretical requirements and Low $=70 \%$ theoretical requirements.

Table 3

Average milk yield $(\mathrm{kg} / \mathrm{d})$, calf birth weight $(\mathrm{kg})$ and calf growth weights $(\mathrm{kg} / \mathrm{d})$ during the constraining (P1) and recovery (P2) periods: influence of body condition at calving (Moderate vs Fat) and post-partum energy level applied during P1 (from 0 to 120 days post-partum).

\begin{tabular}{|c|c|c|c|c|c|c|c|c|c|}
\hline & \multirow{2}{*}{$\begin{array}{l}\mathrm{BCS}_{\mathrm{c}}{ }^{\mathrm{a}} \\
\text { Energy level }^{\mathrm{b}}\end{array}$} & \multicolumn{2}{|c|}{ Moderate } & \multicolumn{2}{|l|}{ Fat } & \multirow[t]{2}{*}{ SEM } & \multicolumn{3}{|c|}{$P$ effects } \\
\hline & & Control & Low & Control & Low & & $\mathrm{BCS}_{\mathrm{c}}$ & Energy & $\mathrm{BCS}_{\mathrm{c}} \times$ Energy \\
\hline \multirow[t]{2}{*}{ Average milk yield $(\mathrm{kg} / \mathrm{d})$} & $\mathrm{P} 1^{\mathrm{c}}$ & 9.2 & 7.0 & 8.3 & 8.7 & 0.6 & ns & ns & ns \\
\hline & $\mathrm{P}^{\mathrm{d}}$ & 7.6 & 7.1 & 6.0 & 6.8 & 0.6 & ns & ns & ns \\
\hline Average calf birth weight $(\mathrm{kg})$ & P1 & 48.0 & 52.0 & 48.0 & 52.0 & 3.2 & ns & ns & ns \\
\hline \multirow[t]{2}{*}{ Average calves growth rates $(\mathrm{kg} / \mathrm{d})$} & P1 & 0.9 & 0.7 & 0.8 & 0.9 & 0.1 & ns & ns & ns \\
\hline & P2 & 0.9 & 0.8 & 0.9 & 1.0 & 0.1 & ns & ns & ns \\
\hline
\end{tabular}

${ }^{\mathrm{a}} \mathrm{BCSC}=$ Body condition score at calving; Moderate: $\mathrm{BCSc}=2.0 \pm 0.04$ and Fat: $\mathrm{BCSC}=2.8 \pm 0.08$.

${ }^{\mathrm{b}}$ Energy levels: energy level supplied during P1 (from 0 to 120 days post-partum); Control $=120 \%$ theoretical requirements and Low $=70 \%$ theoretical requirements.

${ }^{c} n=7$ measurements.

d $n=6$ measurements.

Table 4

Body weight, adipose cell diameter (ACD), body condition score (BCS) and the percentage of lipids in empty body weight at calving, end of constraining period (P1) and end of recovery period (P2): influence of body condition at calving (Moderate vs Fat) and post-partum energy level applied during P1 (from 0 to 120 days post-partum).

\begin{tabular}{|c|c|c|c|c|c|c|c|c|c|}
\hline & \multirow{2}{*}{$\begin{array}{l}\text { BCSc }^{1} \\
\text { Energy level }^{2}\end{array}$} & \multicolumn{2}{|c|}{ Moderate } & \multicolumn{2}{|l|}{ Fat } & \multirow[t]{2}{*}{ SEM } & \multicolumn{3}{|c|}{$P$ effects } \\
\hline & & Control & Low & Control & Low & & $\mathrm{BCS}_{\mathrm{c}}$ & Energy & $\mathrm{BCS}_{\mathrm{c}} \times$ Energy \\
\hline \multirow[t]{4}{*}{ Calving } & $\mathrm{BW}^{3}$ & $760^{\mathrm{a}}$ & $753^{\mathrm{a}}$ & $846^{\mathrm{b}}$ & $852^{\mathrm{b}}$ & 17.6 & $*$ & ns & ns \\
\hline & $\mathrm{ACD}^{4}$ & $54.9^{\mathrm{a}}$ & $52.9^{\mathrm{a}}$ & $79.2^{\mathrm{b}}$ & $80.6^{\mathrm{b}}$ & 3.1 & $* * *$ & ns & ns \\
\hline & $\mathrm{BCS}^{5}$ & $2.0^{\mathrm{a}}$ & $1.9^{\mathrm{a}}$ & $2.8^{\mathrm{b}}$ & $2.8^{\mathrm{b}}$ & 0.1 & $* * *$ & ns & ns \\
\hline & \% Lipids in EBW 6 & $10.7^{\mathrm{a}}$ & $10.7^{\mathrm{a}}$ & $14.2^{\mathrm{b}}$ & $14.4^{\mathrm{b}}$ & 0.4 & $* * *$ & ns & ns \\
\hline \multirow[t]{4}{*}{ End of P1 } & $\mathrm{BW}^{3}$ & $762^{\mathrm{ab}}$ & $720^{b}$ & $835^{a}$ & $810^{\mathrm{ab}}$ & 18.1 & $*$ & $* * *$ & ns \\
\hline & $\mathrm{ACD}^{4}$ & $61.7^{\mathrm{a}}$ & $45.2^{\mathrm{b}}$ & $84.7^{c}$ & $71.4^{\mathrm{d}}$ & 2.4 & $* * *$ & $* * *$ & ns \\
\hline & $\mathrm{BCS}^{5}$ & $1.9^{\mathrm{a}}$ & $1.7^{\mathrm{a}}$ & $2.9^{\mathrm{b}}$ & $2.5^{\mathrm{b}}$ & 0.1 & $* * *$ & $* * *$ & ns \\
\hline & \% lipids in EBW ${ }^{6}$ & $11.3^{\mathrm{a}}$ & $9.6^{\mathrm{b}}$ & $14.6^{\mathrm{c}}$ & $12.8^{\mathrm{d}}$ & 0.4 & $* * *$ & $* * *$ & ns \\
\hline \multirow[t]{4}{*}{ End of P2 } & $\mathrm{BW}^{3}$ & 767 & 776 & 805 & 824 & 19.3 & ns & ns & ns \\
\hline & $\mathrm{ACD}^{4}$ & $67.2^{\mathrm{a}}$ & $56.3^{\mathrm{b}}$ & $86.4^{\mathrm{c}}$ & $70.6^{\mathrm{a}}$ & 3.1 & $* * *$ & $* * *$ & ns \\
\hline & $\mathrm{BCS}^{5}$ & $2.2^{\mathrm{ac}}$ & $2.0^{\mathrm{a}}$ & $2.8^{\mathrm{b}}$ & $2.5^{\mathrm{bc}}$ & 0.1 & $*$ & $* * *$ & ns \\
\hline & \% lipids in EBW 6 & $12.3^{\mathrm{ac}}$ & $11.0^{\mathrm{a}}$ & $14.8^{\mathrm{b}}$ & $13.4^{\mathrm{bc}}$ & 0.5 & $* * *$ & $*$ & ns \\
\hline
\end{tabular}

${ }^{\mathrm{abc}}$ Values within a row with different superscripts differ significantly at $P<0.05$.

${ }^{1} \mathrm{BCS}_{\mathrm{C}}=$ Body condition score at calving; Moderate: $\mathrm{BCS}_{\mathrm{C}}=2.0 \pm 0.04$ and Fat: $\mathrm{BCS}_{\mathrm{C}}=2.8 \pm 0.08$.

2 Energy levels: energy level supplied during P1 (from 0 to 120 days post-partum); Control=120\% theoretical requirements and Low $=70 \%$ theoretical requirements.

${ }^{3} \mathrm{BW}=$ body weight in $\mathrm{kg}$

${ }^{4}$ ACD: adipose cell diameter in $\mu \mathrm{m}$.

${ }^{5}$ BCS: body condition score (0-5 scale).

$6 \%$ lipids in EBW: percentage of lipids in empty body weight. 
As milking suckling beef cows is difficult in practice and that suckled milk composition is not well-known, we have considered that the content of energy of milk consumed by the calf was $3.2 \mathrm{MJ}$ of $\mathrm{NE}_{\mathrm{L}} / \mathrm{kg}$ of milk, which corresponds to $42 \mathrm{~g}$ of fat $/ \mathrm{kg}$ of milk and $33 \mathrm{~g}$ of protein $/ \mathrm{kg}$ of milk (INRA, 2007) in both C and L energy level treatments.

\subsubsection{Body weight and body condition}

During the constraining period, cows were weighed twice a week at $1300 \mathrm{~h}$ with no prior feed withdrawal. During the recovery period, body weights were recorded once a week in the morning $(0900 \mathrm{~h})$. Body condition was assessed twice a month by the same two experienced assessors on a $0-5$ scale (Agabriel et al., 1986).

\subsubsection{Adipose cell diameter and plasma NEFA concentrations}

Subcutaneous adipose tissue was collected by biopsy on the rump after local anaesthesia ( $4 \mathrm{~mL}$ of lidocaine/cow) at calving (start of the constraining period), turnout (end of the constraining period) and end of the recovery period. Adipose tissue samples were placed at $37{ }^{\circ} \mathrm{C}$ and fixed with osmium tetroxide as described by Robelin (1981). Adipocytes were dispersed in $8 \mathrm{M}$ urea solution, and macroscopy was performed to determine the diameter of approximately 300 adipose cells with Optimas software (Optimas Corp., Bothell, WA).

During the constraining period, caudal vein blood samples were collected into evacuated EDTA tubes (Venosafe, TERUMO, EUROPE) once a week before diet distribution, and centrifuged immediately ( $4000 \mathrm{~g}$ for $15 \mathrm{~min}$ at $20^{\circ} \mathrm{C}$ ). The harvested plasma was stored at $-20^{\circ} \mathrm{C}$ until assessment for non-esterified fatty acids (NEFA) by enzymatic colorimetry method (NEFA C Wako method).

\subsubsection{Estimation of body composition, energy retained in tissues and calculated $E_{\text {resid }}$}

EBW was calculated from BW according to the allometric equation proposed by Robelin and Daenicke (1980): $\mathrm{EBW}=c_{0} \times \mathrm{BW}^{\mathrm{C1}}$ where $c_{0}=0.8284$ and $c_{1}=0.8384$. These values for coefficients $c_{0}$ and $c_{1}$ correspond to large frame size beef cows (height at withers in the range 140-150 cm, Garcia and Agabriel, 2008). Total adipose tissue weight (TAD, \% EBW) and empty body lipid weight (LIP, kg) were calculated from adipose cell diameter (ACD, $\mu \mathrm{m})$ using equations proposed by Garcia and Agabriel (2008) based on a Charolais dissection: TAD $=5.211 \times \exp ^{(0.0114 \times \mathrm{ACD})}$ and $\mathrm{LIP}=1.134 \times \mathrm{TAD}^{0.992}$. Empty body protein weight (PROT) was deduced from EBW and LIP by PROT $=($ EBW - LIP $) \times$ 0.20 , it being assumed that the composition of fat-free mass was $20 \%$ protein and $80 \%$ water (Hoch and Agabriel, 2004).

The energy retained in tissues $\left(E_{r}\right)$ as fat and protein can be either mobilized $\left(E_{r}<0\right)$ or deposited $\left(E_{r}>0\right)$ in body reserves. $E_{r}$ was expressed in the same unit as energy intake, namely $\mathrm{NE}_{\mathrm{L}}$. When cows mobilized body reserves, $E_{r}$ was calculated for each relevant period by: $E_{r}=[(($ LIP final - LIP initial $) \times 39.2 \mathrm{MJ})+(($ PROT final - PROT initial $) \times$ $22.9 \mathrm{MJ})] \times 0.8$ assuming that body reserves are used for lactation with a partial efficiency of 0.8 (INRA, 2007). Inversely, when cows gained body reserves, $E_{r}$ was calculated as $E_{r}=[(($ LIP final - LIP initial $) \times 39.2 \mathrm{MJ}) \times 0.6) /$ $0.6]+[(($ PROT final-PROT initial $) \times 22.9 \mathrm{MJ} \times 0.6) / 0.35]$ assuming that the efficiency of utilization of metabolizable energy for fat and protein deposition is 0.6 and 0.35 , respectively and the efficiency of utilization of metabolizable energy for lactation is 0.6 (Geay, 1984; INRA, 2007).

$E_{\text {resid }}$ (expressed in $\mathrm{NE}_{\mathrm{L}}$ ) corresponds to the energy intake minus the energy for milk and tissue growth $\left(E_{r}>0\right)$ or mobilization $\left(E_{r}<0\right)$, and was calculated from equation 1: $E_{\text {resid }}=\mathrm{EI}-\left(E_{l}+E_{y}+E_{r}\right)$, where $\mathrm{EI}$ is the net energy intake $(\mathrm{MJ} / \mathrm{cow} / \mathrm{d}), E_{l}$ is the net energy secreted in milk, $E_{y}$ the net energy retained by the foetus and the gravid uterus and $E_{r}$ is the net energy retained or mobilized by tissues. For each cow, $E_{\text {resid }}$ was calculated over both the constraining and recovery periods. The energy needed for conceptus growth was not taken into account in the $E_{\text {resid }}$ calculation, as reproduction was late, beginning only mid-P2.

\subsection{Statistical analyses}

Data were analysed separately for the constraining and recovery periods. They were all analysed by ANOVA according a $2 \times 2$ factorial design with two main fixed effects: BCS $_{\mathrm{c}}$ and energy levels of diet, and their interaction plus one random effect: the animal using the appropriate MIXED procedure with a covariance structure of compound symmetry and a Satterthwaite degrees of freedom method (SAS, 2010).

More specifically this model was used for digestibility of diet, adipose cell diameter and all variables of body composition (percent of lipids in EBW, changes in EBW and in retained energy in fat and fat-free masses) and $E_{\text {resid. When serial }}$ measurements were performed within each experimental period (BW, Milk production, ADG of calves, body condition and plasma NEFA concentrations) a repeated measures procedure was added to the model. Treatment means were compared by the Tukey's test. Rates of change with time within each experimental period in BW and NEFA plasma concentrations were analysed by a linear mixed procedure, using BW at calving and NEFA concentration at calving as an intra-group covariable, respectively.

Because of a few missing data (see Section 3) all values were expressed as least square means (Lsmeans) with standard error of the mean (SEM). Groups were considered to differ when $P<0.05$.

\section{Results}

Due to ill-health of their calves, three cows were removed from the experiment, leaving 37 cow-calf pairs. Hence, the four treatment groups studied over the nutritional challenge $(\mathrm{P} 1+\mathrm{P} 2)$ were: Fat Control (FC, $n=9)$, Fat Low (FL, $n=9)$, Moderate Control (MC, $n=9$ ) and Moderate Low (ML, $n=10$ ).

\subsection{Diet composition and intake}

The net energy and fill values of dietary ingredients calculated from chemical composition results are reported in Table 1.

During the constraining period, the average energy intakes of $C$ groups was 1.7 fold higher than that of $\mathrm{L}$ groups as 
planned (Table 2). DM digestibility was numerically higher for the $\mathrm{C}$ diet reflecting the higher proportion of concentrates as compared to the $\mathrm{L}$ diet. It did not differ according to $\mathrm{BCS}_{\mathrm{C}}$ $(P=0.54)$ supporting the hypothesis that the net energy value of diets did not differ with body condition.

During the recovery period, grass intake predictions based upon BW, BCS and milk yield did not suggest any differences between treatments (Table 2).

\subsection{Milk production and calf average daily gains}

Over both experimental periods $(\mathrm{P} 1+\mathrm{P} 2)$, the average milk production of groups ranged from 6.0 to $9.2 \mathrm{~kg}$ of milk/d (Table 3). Milk yield of MC cows was numerically the highest $(9.2 \mathrm{~kg}$ of milk/d) but not statistically different from the other groups (Table 3). Peak of milk production was observed between weeks 4 and 6 . Average calf birth weight was similar between groups and calf growth averaged $0.8 \pm 0.09 \mathrm{~kg} / \mathrm{d}$ during the constraining period and $1.1 \pm 0.11 \mathrm{~kg} / \mathrm{d}$ during the recovery period.

\subsection{Body weight dynamics}

Two weeks after parturition, BW of $\mathrm{F}$ and $\mathrm{M}$ cows differed by $93 \mathrm{~kg}(P<0.05$, Table 4 and Fig. 1$)$. During the constraining period, significant differences in BW were observed only between FC and ML groups, intermediate values were noted for the two other groups (Fig. 1). At the end of this period, the differences in BW between $C$ and $\mathrm{L}$ groups reached $43 \mathrm{~kg}$ in $\mathrm{M}$ cows and $25 \mathrm{~kg}$ in $\mathrm{F}$ cows $(P<0.05)$. Changes in BW with time over this period differed $(P<0.01)$. The $C$ energy level treatment led compared to weight gain $(+0.021 \pm 0.04 \mathrm{~kg} /$ day $)$ in $\mathrm{M}$ cows and compared to weight loss $(-0.09 \pm 0.03 \mathrm{~kg} / \mathrm{day})$ in $\mathrm{F}$ cows $(P<0.001)$. The $\mathrm{L}$ energy level resulted in weight loss which was lower $(P<0.001)$ in M cows $(-0.28 \pm 0.03 \mathrm{~kg} / \mathrm{day})$ than in $\mathrm{F}$ cows $(-0.35 \pm 0.04 \mathrm{~kg} /$ day $)$. During the recovery period, BW recovery was significantly greater in the ML group $(+0.74 \pm 0.09 \mathrm{~kg} /$ day over the period $)$ than in the other groups (FC: $-0.31 \pm 0.09 \mathrm{~kg} /$ day, MC: $+0.06 \pm 0.08$ and FL: $+0.2 \pm$ $0.09 \mathrm{~kg} /$ day, respectively). At the end of the experiment, the difference in BW observed at the start was numerically halved from 20 to $9 \mathrm{~kg}$ between $\mathrm{F}$ and M cows, respectively (Table 4, Fig. 1).

\subsection{Body lipid reserves dynamics}

At calving, BCS and adipose cell diameter measurements, as well as the amount of body lipids in EBW, confirmed expected differences in body lipid reserves between $\mathrm{M}$ and $\mathrm{F}$ cows $(P<0.001$, Table 4$)$. BCS $_{\mathrm{c}}$ was significantly lower in $\mathrm{M}$ than in F cows $(2.0 \pm 0.04$ and $2.8 \pm 0.08$, Table 4). Adipose cell diameters were $32 \%$ lower in $\mathrm{M}$ than in $\mathrm{F}$ cows $(53.4 \pm 1.7$ vs $78.1 \pm 1.7, P<0.001$ ), and body lipids calculated in EBW were $25 \%$ lower in $\mathrm{M}$ cows $(10.7 \pm 0.3 \%$ vs $14.3 \pm 0.3 \%$, $P<0.001)$. At the end of P1, body lipid reserves of cows differed between $\mathrm{BCS}_{\mathrm{C}}(\mathrm{M}$ vs $\mathrm{F})$ and energy level treatments ( $\mathrm{L}$ vs $C)(P<0.001$, Table 4$)$. The M cows showed lower ACD, BCS and percent of lipid in EBW than F cows $(P<0.001)$. L energy level resulted in a decrease of $26 \%$ of ACD in M and $15 \%$ in $F$ cows $(P<0.001)$ respectively during $P 1$. The combined effects of $\mathrm{BCS}_{\mathrm{c}}$ and post partum energy level resulted in a decrease in

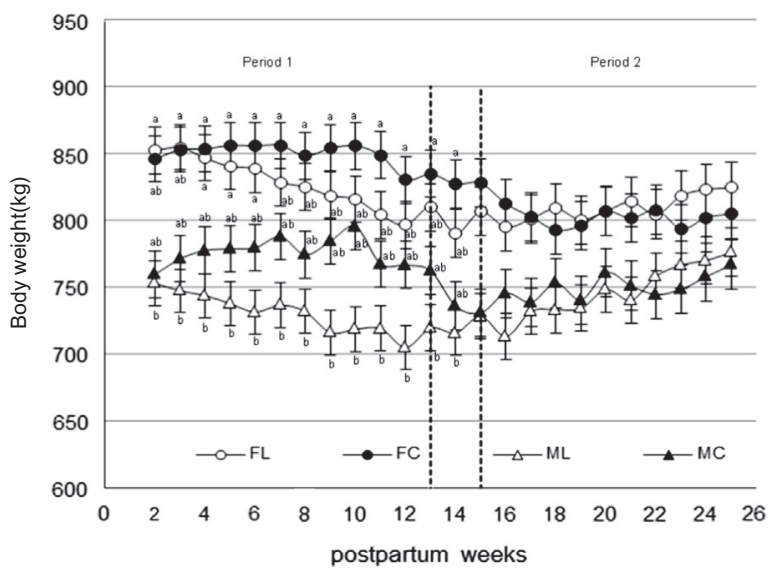

Fig. 1. Time course of mean body weight during constraining (P1) and recovery periods ( $\mathrm{P} 2$ ) according to the body condition at calving (Moderate, $\mathrm{M}, \mathrm{BCS}_{\mathrm{c}}=2.0 \pm 0.04$ vs Fat, $\mathrm{F}, \mathrm{BCS}_{\mathrm{c}}=2.8 \pm 0.08, P<0.0001$ ) and the post partum energy level applied during $\mathrm{P} 1$ from 0 to 120 days post partum (Control $=120 \%$ theoretical requirements and Low $=70 \%$ theoretical requirements).

the proportion of lipids in EBW of 15\% in $\mathrm{M}$ cows and 12\% in $\mathrm{F}$ cows at the end of P1. At the end of P2, ACD of L cows was significantly lower than that of $\mathrm{C}$ cows whatever the $\mathrm{BCS}_{\mathrm{c}}$. BCS and estimation of percentage of lipids in EBW did not differ between the two energy levels within the $\mathrm{M}$ and $\mathrm{F}$ groups (Table 4). Only the cows belonging to the most contrasting $\mathrm{BCS}_{\mathrm{c}}$ and energy level treatment groups (ML vs FC) presented significant differences in body lipid reserves (Table 4). Over the recovery period, the recovery of body lipid reserves was proportionately highest in ML cows (ACD: $+24.5 \%, P<0.05$; \% lipids in EBW: $+14.6 \%, P<0.01$ ) (Table 4).

Variations of plasma NEFA concentrations throughout the constraining period are depicted in Fig. 2. At parturition, mean NEFA concentrations did not differ significantly between $\mathrm{F}$ and $\mathrm{M}$ cows $(0.31 \pm 0.04$ vs $0.23 \pm 0.05 \mathrm{mmol} / \mathrm{L})$. The $\mathrm{L}$ energy level treatment resulted in an increase of plasma NEFA concentrations for the $\mathrm{M}$ and $\mathrm{F}$ groups, with peak values reached during the first month of lactation $(0.47 \pm 0.09$ and $0.45 \pm 0.07 \mathrm{mmol} / \mathrm{L}$, respectively). NEFA concentrations in L groups decreased thereafter, with a high variability between cows. In both C groups (FC and MC), NEFA concentrations remained at a low and similar level during the constraining period $(0.13 \pm 0.027$ and $0.14 \pm 0.027 \mathrm{mmol} / \mathrm{L}$ in FC and MC groups, respectively).

\subsection{Changes in body composition and energy allocation}

Changes in body composition and estimates of $E_{r}$ and $E_{\text {resid }}$ during both experimental periods are reported in Table 5 . During the constraining period, variations in EBW, fat and protein masses differed only according to the energy level treatment $(P<0.01)$. Variations in EBW during this period were higher in $\mathrm{L}$ than in $\mathrm{C}$ cows whatever the $\mathrm{BCS}_{\mathrm{C}}(-33.5 \mathrm{vs}$ $+2.5 \mathrm{~kg}$ in ML and MC respectively and $-42.5 \mathrm{vs}-11.4 \mathrm{~kg}$ in FL and FC respectively, Table 5). Such variations were also observed for fat and protein masses. The $\mathrm{C}$ cows showed a slight decrease in protein mass (MC: $-0.2 \pm 1.96$ and FC: $-2.5 \pm 1.96 \mathrm{~kg}$ ) and a low gain of fat mass (MC: $3.4 \pm 2.59$ and FC: $1.2 \pm 2.59 \mathrm{~kg}$ ) (Table 5). 


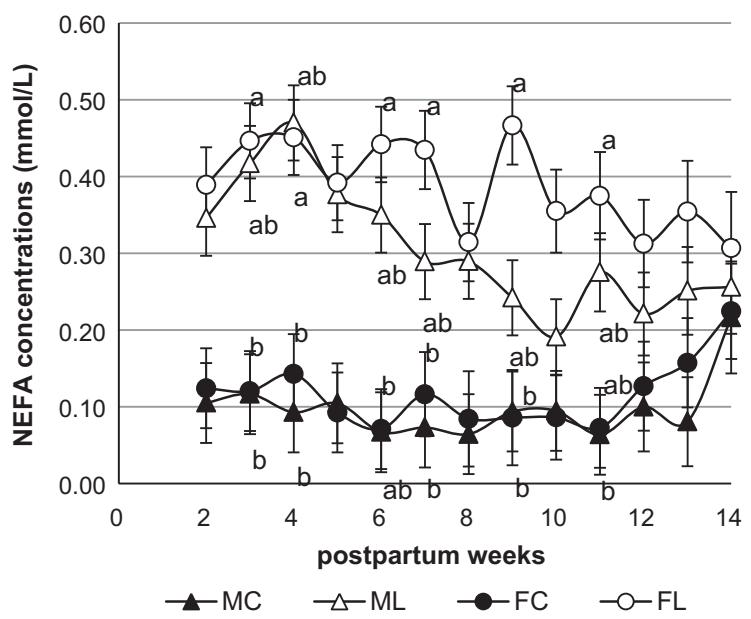

Fig. 2. Time course of plasma concentrations of non-esterified fatty acid $(\mathrm{mmol} / \mathrm{L}$ ) over P1 according to body condition at calving (Moderate, M, $\mathrm{BCS}_{\mathrm{C}}=2.0 \pm 0.04$ vs Fat, $\left.\mathrm{F}, \mathrm{BCS}_{\mathrm{C}}=2.8 \pm 0.08, P<0.0001\right)$ and the post partum energy level applied during $\mathrm{P} 1$ from 0 to 120 days post partum (Control $=120 \%$ theoretical requirements and Low $=70 \%$ theoretical requirements).

As expected, during the constraining period EI was 1.45 and 1.3 times higher in MC and FC cows than in ML and FL cows, respectively. Expressed per metabolic BW, these intakes were close to planned values $\left(0.60\right.$ vs $0.42 \mathrm{MJ} / \mathrm{d} / \mathrm{kg}^{0.75}$ in the $\mathrm{M}$ group and 0.68 vs $0.51 \mathrm{MJ} / \mathrm{d} / \mathrm{kg}^{0.75}$ in the $\mathrm{F}$ group). Body composition changes led to positive or negative variations in net energy retained in tissues $\left(E_{r}\right)$. $E_{\text {resid }}$ was affected both by $\mathrm{BCS}_{\mathrm{c}}$ and the post-partum energy level treatment during the constraining period $(P<0.001)$. The L energy level decreased $E_{\text {resid }}$ compared with the $\mathrm{C}$ level by $25 \%$ and $27 \%$ in $\mathrm{M}$ and $\mathrm{F}$ cows, respectively (MC: 0.35 vs ML: 0.26 and FC: 0.47 vs FL: $\left.0.34 \mathrm{MJ} / \mathrm{d} / \mathrm{kg} \mathrm{BW}{ }^{0.75}, P<0.001\right)$. During the recovery period, EBW, body composition changes and $E_{r}$ were affected by both $\mathrm{BCS}_{\mathrm{c}}$ and energy level treatment $(P<0.01)$. During the recovery period, EBW decreased in FC cows $(-29.8 \mathrm{~kg})$ in contrast to the three other groups, where EBW variations ranged from +4.7 to $+56.5 \mathrm{~kg}$ (Table 5). The decrease in EBW in FC cows was linked with a decrease in both fat $(-3.3 \mathrm{~kg})$ and protein masses $(-5.3 \mathrm{~kg})$. In the three other groups (FL, MC and ML), a significant reconstitution of both fat and protein masses was observed during the recovery period (Table 5), and resulted in positive values of $E_{r}$. During the recovery period, $E_{\text {resid }}$ was lowest in ML cows $\left(0.36 \pm 0.08 \mathrm{MJ}\right.$ of $\left.\mathrm{NE}_{\mathrm{L}} / \mathrm{d} / \mathrm{kg} \mathrm{BW} \mathrm{BW}^{0.75}\right)$ and highest in $\mathrm{FC}$ cows $\left(0.49 \pm 0.07 \mathrm{MJ}\right.$ of $\left.\mathrm{NE}_{\mathrm{L}} / \mathrm{d} / \mathrm{kg} \mathrm{BW}^{0.75}\right) . \mathrm{MC}$ and FL cows showed intermediate values $(0.41 \pm 0.08$ and $0.43 \pm 0.05 \mathrm{MJ}$ of

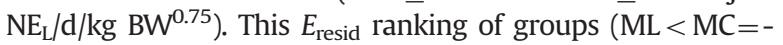
$\mathrm{FL}<\mathrm{FC}, P<0.05)$ was also observed over the overall experiment $(\mathrm{P} 1+\mathrm{P} 2)$, with values ranging from 0.32 to $0.49 \mathrm{MJ} / \mathrm{d} / \mathrm{kg}$ $\mathrm{BW}^{0.75}$ (data not shown).

\section{Discussion}

According to the concept of reaction norm (Bryant et al., 2006), robustness in cows is defined as the capacity to maintain function and resilience when facing environmental disturbances (Strandberg, 2009). Such a capacity relies on adaptive abilities of animals that may involve trade-off between life functions when the environment becomes limiting (Blanc et al., 2006, 2013; Friggens and Newbold, 2007). Maintaining milk production in suckling beef cows despite feed restriction reflects prioritization for this function and robustness. This study used an indirect approach to evaluate the modulation of energy allocation in lactating mature beef cows. The difference of residual energy between the non limiting and the changing nutritional trajectories $\left(\Delta E_{\mathrm{resid}}\right)$ calculated over the entire experiment reflects changes in energy allocation to life functions. This criterion was evaluated by comparing groups following different trajectories because $\Delta E_{\text {resid }}$ cannot be calculated for each individual cow.

The choice was made to express $E_{\text {resid }}$ as a net energy value in line with the INRA feed evaluation system. Interpretation of absolute values of $E_{\text {resid }}$ depends on it; nevertheless, it is possible to compare the relative values between groups according to the nutritional trajectory of cows and their body condition at calving.

The dietary energy intake over the constraining period was calculated for the two feeding treatments. No differences in diet digestibility were observed between groups of cows, which suggests that variations in $E_{\text {resid }}$ are not due to differences in digestibility. During the recovery period, EI was estimated for each cow according to the fill unit system applied at grass as proposed Faverdin et al. (2011). As cows were managed together on the same plots, errors in estimations of EI were assumed to be equal between groups of cows.

In this trial, the milk production did not differ significantly between groups. Few data are available concerning milk composition in beef cows. In dairy cows, the composition of milk and especially the protein content vary with the level of energy intake (Coulon and Remond, 1991). Variations in protein content averaged $0.08 \mathrm{~g}$ per $\mathrm{kg}$ of milk/MJ of ME of diet. By contrast, variations in milk fat content are independent of variations in milk production and protein content (Coulon and Remond, 1991). Milk fat content is affected by numerous factors such as the proportion of concentrate in diet, its composition and the feed distribution. However, when the proportions of concentrate in diet increased from 0 to $40 \%$, variations in fat content were relatively small increasing by $0.04 \mathrm{~g} / \mathrm{kg} / \mathrm{MJ}$ of ME which only tends to compensate the decrease in milk energy content due to the decrease in protein content (Journet and Chilliard, 1985). In our experimental conditions, it is not possible to determine the milk composition. During the first month of the constraining period, L cows mobilized body fat (Fig. 2) which may increase milk fat content, nevertheless the milk yield production being moderate and to simplify, we assumed that milk composition was constant whatever the $\mathrm{BCS}_{\mathrm{c}}$ and energy level supplied. The energy secreted in milk was then assumed to be similar between groups. This result suggests the priority of energy allocation in favour of the preservation of milk production when the energy provided by the environment is limited. If validated by direct measurements in future studies, this would confirm the priority of the lactation function (maternal investment) in suckling beef cows. Such a priority would imply that the energy allocation among life functions other than lactation has been modified.

Amounts and variations between $\mathrm{C}$ and $\mathrm{L}$ treatments in calculated $E_{\text {resid }}$ have been observed between groups of cows and ranged from 12 to $27 \%$ according to body condition at 
Table 5

Empty body weight changes, fat and protein mass $(\mathrm{kg})$ changes, energy intake (EI), energy in milk production $\left(E_{l}\right)$, energy in body tissues $\left(E_{r}\right)$ and residual energy $\left(E_{\text {resid }}\right)$ during constraining (P1) and recovery (P2) periods: influence of body condition at calving (Moderate vs Fat) and post-partum energy level applied during P1 (from 0 to 120 days post-partum). All energy variables are expressed in $\mathrm{NE}_{\mathrm{L}}$.

\begin{tabular}{|c|c|c|c|c|c|c|c|c|c|}
\hline & \multirow{2}{*}{$\begin{array}{l}\text { BCS }_{\mathrm{c}}{ }^{1} \\
\text { Energy level }^{2}\end{array}$} & \multicolumn{2}{|c|}{ Moderate } & \multicolumn{2}{|l|}{ Fat } & \multirow[t]{2}{*}{ SEM } & \multicolumn{3}{|c|}{$P$ effects } \\
\hline & & Control & Low & Control & Low & & $\mathrm{BCS}_{\mathrm{c}}$ & Energy & $\mathrm{BCS}_{\mathrm{c}} \times$ Energy \\
\hline \multirow[t]{8}{*}{ over P1 } & EBW change $(\mathrm{kg})^{3}$ & $2.5^{\mathrm{a}}$ & $-33.5^{\mathrm{ab}}$ & $-11.4^{\mathrm{ab}}$ & $-42.5^{\mathrm{b}}$ & 11.3 & ns & $* *$ & ns \\
\hline & Fat mass change (kg) & $3.4^{\mathrm{a}}$ & $-10.2^{\mathrm{b}}$ & $1.2^{\mathrm{a}}$ & $-15.6^{\mathrm{b}}$ & 2.6 & ns & $* * *$ & ns \\
\hline & Protein mass change (kg) & -0.2 & -4.7 & -2.5 & -5.4 & 2.0 & ns & ns & ns \\
\hline & $\mathrm{EI}(\mathrm{MJ} / \mathrm{d})^{4}$ & $73.7^{\mathrm{a}}$ & $50.7^{\mathrm{b}}$ & $88.0^{c}$ & $65.7^{\mathrm{d}}$ & 1.2 & $* * *$ & $* * *$ & ns \\
\hline & $E_{l}(\mathrm{MJ} / \mathrm{d})^{5}$ & 29.2 & 22.2 & 26.6 & 27.2 & 1.9 & ns & ns & ns \\
\hline & $E_{r}(\mathrm{MJ} / \mathrm{d})^{6}$ & $1.5^{\mathrm{a}}$ & $-3.4^{\mathrm{b}}$ & $0.4^{\mathrm{a}}$ & $-4.9^{\mathrm{b}}$ & 1.0 & ns & $* * *$ & ns \\
\hline & $E_{\text {resid }}(\mathrm{MJ} / \mathrm{d})^{7}$ & $43.0^{\mathrm{a}}$ & $31.8^{\mathrm{b}}$ & $60.9^{c}$ & $43.4^{\mathrm{a}}$ & 1.7 & $* * *$ & $* * *$ & ns \\
\hline & $E_{\text {resid }}\left(\mathrm{MJ} / \mathrm{d} / \mathrm{kg} \mathrm{BW}^{0,75}\right)^{8}$ & $0.35^{\mathrm{a}}$ & $0.26^{\mathrm{b}}$ & $0.47^{\mathrm{c}}$ & $0.34^{\mathrm{a}}$ & 0.02 & $* * *$ & $* * *$ & ns \\
\hline \multirow[t]{8}{*}{ over P2 } & EBW change $(\mathrm{kg})^{3}$ & $4.7^{\mathrm{a}}$ & $56.5^{\mathrm{b}}$ & $-29.8^{\mathrm{ab}}$ & $14.6^{\mathrm{ab}}$ & 13.7 & $* *$ & $* * *$ & Ns \\
\hline & Fat mass change $(\mathrm{kg})$ & $7.1^{\mathrm{ab}}$ & $14.1^{\mathrm{a}}$ & $-3.3^{\mathrm{b}}$ & $5.6^{\mathrm{ab}}$ & 3.8 & $* *$ & $* *$ & ns \\
\hline & Protein mass change (kg) & $-0.5^{\mathrm{a}}$ & $8.5^{\mathrm{b}}$ & $-5.3^{\mathrm{a}}$ & $1.8^{\mathrm{ab}}$ & 2.4 & $*$ & $* * *$ & ns \\
\hline & $\mathrm{EI}(\mathrm{MJ} / \mathrm{d})^{4}$ & 78.8 & 77.5 & 74.4 & 80.8 & 1.3 & ns & ns & ns \\
\hline & $E_{l}(\mathrm{MJ} / \mathrm{d})^{5}$ & 24.3 & 22.3 & 18.6 & 21.7 & 1.9 & ns & ns & ns \\
\hline & $E_{r}(\mathrm{MJ} / \mathrm{d})^{6}$ & $4.1^{\mathrm{a}}$ & $11.6^{\mathrm{ab}}$ & $-2.2^{\mathrm{b}}$ & $4.3^{\mathrm{ab}}$ & 2.3 & $* *$ & $* *$ & ns \\
\hline & $E_{\text {resid }}(\mathrm{MJ} / \mathrm{d})^{7}$ & $50.4^{\mathrm{ab}}$ & $43.5^{\mathrm{a}}$ & $62.1^{\mathrm{b}}$ & $54.8^{\mathrm{ab}}$ & 3.0 & $* *$ & $*$ & ns \\
\hline & $E_{\text {resid }}\left(\mathrm{MJ} / \mathrm{d} / \mathrm{kg} \mathrm{BW}^{0,75}\right)^{8}$ & $0.41^{\mathrm{ab}}$ & $0.36^{\mathrm{a}}$ & $0.49^{\mathrm{b}}$ & $0.43^{\mathrm{ab}}$ & 0.03 & $* *$ & $*$ & ns \\
\hline
\end{tabular}

${ }^{\text {abc } V a l u e s ~ w i t h i n ~ a ~ r o w ~ w i t h ~ d i f f e r e n t ~ s u p e r s c r i p t s ~ d i f f e r ~ s i g n i f i c a n t l y ~ a t ~} P<0.05$

${ }^{1} \mathrm{BCS}_{\mathrm{c}}=$ Body condition score at calving; Moderate: $\mathrm{BCS}_{\mathrm{c}}=2.0 \pm 0.04$ and Fat: $\mathrm{BCS}_{\mathrm{c}}=2.8 \pm 0.08$.

${ }^{2}$ Energy level: energy level supplied during P1 (from 0 to 120 days post-partum); Control=120\% theoretical requirements and Low $=70 \%$ theoretical requirements.

${ }^{3}$ EBW: body weight.

${ }^{4}$ EI: energy intake (measured over P1 and estimated over P2) expressed in megajoules per day of net energy for lactation.

${ }^{5} E_{l}$ : energy for milk production expressed in megajoules per day of net energy for lactation.

${ }^{6} E_{r}$ : energy retained in tissues expressed in megajoules per day of net energy for lactation.

${ }^{7} E_{\text {resid }}$ : energy residual corresponding to the energy intake minus the energy for milk and tissue growth expressed in megajoules per day of net energy for lactation.

${ }^{8} E_{\text {resid }}$ : energy residual corresponding to the energy intake minus the energy for milk and tissue growth expressed in megajoules per day and per kg of body metabolic weight of net energy for lactation.

calving and the period. Changes in body composition and energy expenditures could be involved in this response to the nutritional challenge as proposed by Williams and Jenkinks (2003) in their model of energy utilization in mature cattle. At the end of the constraining period, $E_{\text {resid }}$ in the low energy feeding level cows was lower than in control energy level cows (close to $-25 \%$ ) regardless of $\mathrm{BCS}_{\mathrm{c}}$. Such variations in $E_{\text {resid }}$ could be partly explained by variations in heat production losses and in maintenance requirements linked with body composition changes. Indeed, a similar decrease in heat production (measured in respiratory chambers) due to a low feeding level was previously observed in mature nonpregnant non-lactating Charolais (Ortigues et al., 1993) or composite cows (Freetly and Nienaber, 1998). In these two studies, a non-linear weight loss pattern occurred within the first 14 days after the feeding level change and no further adaptation of energy metabolism with time was reported (Ortigues et al., 1993). A similar dynamic pattern of body weight change was observed in the present study for L cows. BW changes are associated with variations in adipose reserves. The fat loss in L groups was confirmed by both the decrease in ACD and the increase in plasma concentrations of NEFA within the first 28 days after the beginning of feed restriction as previously noticed by Agenas et al. (2006). Variations over time in the amounts of body adipose tissue as indicated by NEFA concentrations followed a similar pattern to body weight, with a rapid decrease early after the start of feed restriction followed by a slower decrease as feed restriction was prolonged.

During the recovery period, amounts of $E_{\text {resid }}$ were higher than those calculated over the constraining period in both $\mathrm{L}$ and $\mathrm{C}$ feeding levels. Nevertheless, a 12\% difference between the two nutritional trajectories remained whatever the $\mathrm{BCS}_{\mathrm{c}}$. These observations are certainly in part linked to an increase in intake and a process observed in recovery growth called rebound (Hoch et al., 2003; Hornick et al., 2000). When the nutritional constraint is removed, a lag is observed before the gradual increase in the energy metabolism that will enable the underfed cows to recover their weight and body condition (Agabriel and Petit, 1987; Freetly et al., 2000). Although varying according to many factors, this delay in energy metabolism recovery occurred within the first month of the recovery period (Freetly and Nienaber, 1998). During this period, body weight gain changes were almost linear. At the end of this latter, underfed cows had recovered a large part of their initial body weight and body condition.

Considering both experimental periods ( $\mathrm{P} 1+\mathrm{P} 2,196$ days), a low feeding level followed by a recovery period at pasture resulted in a decrease of more than $20 \%$ of $E_{\text {resid }}$ in both moderate and fat cows, without affecting milk production, final body weight or body condition. These results suggest that changing nutritional trajectories (underfeeding/refeeding) resulted in differences in energy allocation between functions and modulated the available nutrient partitioning and use in 
response to environmental pressure (Friggens and Newbold, 2007). From a practical point of view, a robust cow keeping its milk production constant when feed allowances are restricted will have a lower $E_{\text {resid }}$. In this respect, $E_{\text {resid }}$ could be a useful indicator of robustness.

In our study, no interaction between initial body reserves and energy level of the diet was observed. Lean cows exhibited similar $E_{\text {resid }}$ changes than fatter cows when they were subjected to an underfeeding/refeeding trajectory, suggesting that there was no difference in prioritization of energy allocation. This could be different with thinner cows or with cows of higher milk potential. Various authors previously reported the importance of body adipose reserves to buffer differences between energy supply and needs which enable animals to cope with constraining nutritional environments (Petit and Agabriel, 1993; Blanc et al., 2006). Under our experimental conditions, we can conclude that the ability of suckling cows to cope with a nutritional challenge occurring after calving is similar between fatter and leaner cows, and depends on the adaptive abilities of cows to modulate the energy allocation between functions.

\section{Conclusions}

This study illustrates the ability of suckling Charolais cows to maintain milk production when experiencing variable nutritional trajectories. Within changing nutritional trajectories, the robustness of Charolais cows relies on changes in energy resource allocation between life functions as weight and body composition vary. Our results show that robustness for milk production is weakly sensitive to body condition, because lean cows exhibited similar abilities to fat ones to cope with a nutritional challenge.

Long-term nutritional changes give an opportunity to measure variations in calculated $E_{\text {resid. }} E_{\text {resid }}$ changes reflect safeguarding of energy allocation to life functions and could be considered as an indirect criterion of robustness.

These findings require further investigations especially to validate the relevance of $E_{\text {resid }}$ as a trait of robustness in a changing nutritional environment. It is a major issue, as ruminant livestock production will have to face more changing nutritional environments in the future.

\section{Conflict of interest}

None of the authors have any conflicts of interest regarding this manuscript.

\section{Acknowledgments}

The authors wish to thank the staff of the experimental farm (Laqueuille) for their assistance throughout the course of this study as well as Isabelle Constant for her excellent technical assistance.

\section{References}

Agabriel, J., Giraud, J-M., Petit, M., 1986. Détermination et utilisation de la note d'engraissement en élevage allaitant. Bull. Tech. CRZV Theix INRA 66, 43-50.
Agabriel, J., Petit, M., 1987. Recommandations alimentaires pour les vaches allaitantes. Bull. Tech. CRZV Theix INRA 70, 153-166.

Agenas, S., Heath, M.F., Nixon, R.M., Wilkinson, J.M., Phillips, C.J.C., 2006. Indicators of undernutrition in cattle. Anim. Welf. 15, 149-160.

Aufrère, J., Baumont, R., Peccatte, J-R., Andrieu, J., Dulphy, J-P., 2007. Prévision de la digestibilité des fourrages par la méthodes pepsinecellulase. Le point sur les équations proposées. INRA Prod. Anim 20, 129-136.

Blanc, F., Bocquier, F., Agabriel, J., D'Hour, P., Chilliard, Y., 2006. Adaptive abilities of the females and sustainability of ruminant livestock systems. A review. Anim. Res. 55, 489-510.

Blanc, F., Ollion, E., Puillet, L., Delaby, L., Ingrand, S., Tichit, M., Friggens, N., 2013. Evaluation quantitative de la robustesse des animaux et du troupeau: quels principes retenir? Renc. Rech. Ruminants 2013 (20), 265-272.

Bryant, J.R., Lopez-Villalobos, N., Pryce, J.E., Holmes, C.W., Johnson, D.L., 2006. Reaction norms used to quantify the responses of New Zealand dairy cattle of mixed breeds to nutritional environment. N. Z. J. Agric. Res, 49, 371-381.

Chilliard, Y., Bocquier, F, Doreau, M., 1998. Digestive and metabolic adaptations of ruminants to undernutrition, and onsequences on reproduction. Reprod. Nutr. Dev. 38, 131-152.

Coulon, J-B., Remond, B., 1991. Variations in milk output and milk protein in response to the level of energy supply to the dairy cow: a review. Livest. Prod. Sci. 29, 31-47.

Delagarde, R., Pérez-Ramírez, E., Peyraud, J-L., 2010. Ytterbium oxide has the same accuracy as chromic oxide for estimating variations of faecal dry matter output in dairy cows fed a total mixed ration at two feeding levels. Anim. Feed Sci. Technol. 161, 121-131.

Douhart, F., 2013. Towards Resilient Livestock Systems: A Resource Allocation Approach to Combine Selection and Management within the Herd Environment. Ph.D. manuscript, 177 p.

Ellis, W.C., Lascano, C., Teeter, R., Owens, F.N., 1982. In: Owens, F.N. (Ed.), Solute and particulate flow markers. In: Protein Requirements for Cattle, Symposium Oklahoma State University, Stillwater, pp. 37-56.

Faverdin, P., Baratte, C., Delagarde, R., Peyraud, J-L., 2011. GrazeIn: a model of herbage intake and milk production for grazing dairy cows. 1. Prediction of intake capacity, voluntary intake and milk production during lactation. Grass Forage Sci. 66, 29-44.

Freetly, H.C., Nienaber, J.A., 1998. Efficiency of energy and nitrogen loss and gain in mature cows. J. Anim. Sci. 76, 896-905.

Freetly, H.C., Ferrell, C.L., Jenkins, T.G., 2000. Timing of realimentation of mature cows that were feed-restricted during pregnancy influences calf birth and growth rates. J. Anim. Sci. 78, 2790-2796.

Friggens, N.C., Newbold, J.R., 2007. Towards a biological basis for predicting nutrient partitioning: the dairy cow as an example. Animal $1,87-97$.

Friggens, N.C., Brun-Lafleur, L., Faverdin, P., Sauvant, D., Martin, O., 2013. Advances in predicting nutrient partitioning in the dairy cow: recognizing the central role of genotype and its expression through time. Animal 7, 89-101.

Garcia, F., Agabriel, J., 2008. CompoCow: a predictive model to estimate variations in body composition and the energy requirements of cull cows during finishing. J. Anim. Sci. 146, 251-265.

Geay, Y., 1984. Energy and protein-utilization in growing cattle. J. Anim. Sci. 58, 766-778.

Hoch, T., Begon, C., Cassar-Malek, I., Picard, B., Savary-Auzeloux, I., 2003. Mécanismes et conséquences de la croissance compensatrice chez les ruminants. INRA Prod. Anim 16, 49-59.

Hoch, T., Agabriel, J., 2004. A mechanistic dynamic model to estimate beef cattle growth and body composition: 1. Model description. Agric. Syst. 81, 1-15.

Hornick, J-L, Eenaeme, C.V., Gérard, O., Dufrasne, I., Istasse, L., 2000. Mechanisms of reduced and compensatory growth. Domest. Anim. Endocrinol. 19, 121-132.

Houghton, P.L., Lemanager, R.P., Horstman, L.A., Hendrix, K.S., Moss, G.E., 1990. Effects of body composition, pre- and postpartum energy level and early weaning on reproductive performance of beef cows and preweaning calf gain. J. Anim. Sci. 68, 1438-1446.

INRA, 2007. Alimentation des bovins, ovins et caprins. Besoins des animaux -valeurs des aliments, Quae Edition, Versailles, France, 307 p.

Jarrige, R.E., 1989. Ruminant Nutrition-Recommended Allowances \& Feed Tables". INRA, France389 p.

Jenkins, T.G., Ferrell, C.L., 1994. Productivity through weaning of nine breeds of cattle under varying feed availabilities: I. Initial evaluation. J. Anim. Sci. 72, 2787-2797.

Johnson, D.E., Ferrell, C.L., Jenkins, T.G., 2003. The history of energetic efficiency research: where we have been and where we are going? J. Anim. Sci 81, 27-38. 
Journet, M., Chilliard, Y., 1985. Influence de l'alimentation sur la composition du lait-1-Taux butyreux: facteurs généraux. Bull. Tech. CRZV Theix INRA 60, 13-24.

Kirkland, R., Gordon, F.J., 2001. The effects of milk yield and stage of lactation in the partitionng of nutrient in lactating dairy cows. J. Dairy Sci. $84,233-240$.

Kitano, H., 2004. Biological robustness. Nat. Rev. Genet. 5, 826-837.

Knap, P.W., 2005. Breeding robust pigs. Anim. Prod. Sci. 8, 763-773.

Le Neindre, P., Dubroeucq, $H$. 1973. Observations sur l'estimation de la production laitière des vaches allaitantes par la pesée du veau avant et après tétée. Ann. Zoot 22, 413-422.

Martin, O., Sauvant, D., 2010. A teleonomic model describing performance (body, milk and intake) during growth and over repeated reproductive cyclesthroughout the lifespanof dairy cattle. Animal 4, 2030-2047.

Ortigues, I., Petit, M., Agabriel, J., Vermorel, M., 1993. Maintenance requierements in metabolizable energy of adult, non pregnant, non lactating charolais cows. J. Anim. Sci. 71, 1947-1956.

Osoro, K, Wright, I.A., 1992. The effect of body condition, live weight, breed, age, calf performance and calving date on reproductive performance of spring-calving beef cows. J. Anim. Sci. 70, 1661-1666.
Petit, M., Agabriel, J., 1993. Body reserves of suckling Charolais cows: their significance, practical value and relationship with reproduction. INRA Prod. Anim. 6, 311-318.

Robelin, J., 1981. Cellularity of bovine adipose tissues. Developmental changes from 15 percent to 65 percent mature weight. J. Lipid Res. 22 452-457.

Robelin, J., Daenicke, R., 1980. Variations of net requirements for cattle growth with liveweight, liveweight gain, breed and sex. Energy and protein feeding standards applied to the rearing and finishing of beef cattle. In: Proceedings of a Seminar in the EEC Programme of Research on Beef Production, 13-16 November 1979, Theix, France, pp. 99-118.

SAS, 2010. Enterprise Guide Version 4.3. SAS Institute Inc., Cary, NC, USA Copyright 2006-2010.

Strandberg, E., 2009. In: Klopčič, M., Reents, R., Philipsson, J., Kuipers, A (Eds.), Breeding for Robustness in Cattle, Wageningen Academic Publishers, The Netherlands, pp. 17-34.

Williams, C.B., Jenkinks, T.G., 2003. A dynamic model of metabolizable energy utilization in growing and mature cattle. I. Metabolizable energy utilization for maintenance and support metabolism. J. Anim. Sci. $81,1371-1381$ 